\title{
Manisa Celal Bayar Üniversitesi Uygulamalı Bilimler Yüksekokulu Bankacılık ve Finans Bölümü Mezunu Öğrencilerinin Ekonomiye Katkılarının Tespitine Yönelik Bir Araştırma
}

\author{
Hatice Nur Germira,b, Hakan Atlı ${ }^{c}$ \\ Özet
}

Bu çalışmada, gelişmiş ve gelişmekte olan ülkelerde işletmelerin vasıflı ara eleman ihtiyacını karşılamada, Meslek Yüksekokullarının ve onun bir üst versiyonu olan Uygulamalı Bilimler Yüksekokullarını öneminin yadsınamaz bir gerçek olduğundan hareketle, bankacılık ve finans sektörlerinde çalışacak meslek elemanı yetiştirmeye gayret gösteren okulumuzdan 2006-2019 yılları arasında mezun olan öğrencilerimiz incelenmiştir. Yapılan araştırma sonuçlarına göre öğrencilerin mesleki eğitimde beklenti ve motivasyonlarının genel olarak yüksek düzeyde olduğunu, bu durumun öğrencilerin günümüzde daha çok bilinçlendiklerini ve ne istediklerinin daha farkında olduklarını ortaya koymaktadır. Bu kapsamda Manisa Celal Bayar Üniversitesi Uygulamalı Bilimler Yüksekokulu Bankacılık ve Finans Bölümü mezun öğrencilerinden 234 öğrenciye 26 sorudan oluşan anket uygulanmıștır. Ankete verilen cevaplardaki ifadelerin dağılımları frekans analizleri ile yapılmıştır. Tüm analizler SPSS 16.0 programında gerçekleştirilmiştir. Buna göre istihdam edilen 181 kişiden yüzde $52.5^{\prime}$ ini oluşturan 95 kişinin üniversite hayatında okudukları bankacılık ve finans bölümleriyle alakalı sektörlerde çalıştı̆̆ı, istihdam edilenlerin yüzde 63'ünün özel sektörde, yüzde 32.6'sının kamu sektöründe olduğu ve mezun öğrencilerimizin yüzde 4.4.'ünün kendi işinin sahibi olarak girişimci oldukları sonuçlarına varılmıştır.

Anahtar Kelimeler

\begin{tabular}{r} 
Anahtar Kelimeler \\
Mezun \\
Kariyer \\
İstihdam \\
Ekonomiye Katkı \\
Makale Hakkında \\
\hline Geliş Tarihi: 30.08 .2021 \\
Kabul Tarihi: 15.12.2021 \\
Doi: 10.18026/cbayarsos.988518 \\
\hline Economy of Graduate \\
plied Sciences, Banking
\end{tabular}

Keywords

Graduate

Career

Employment

Contribution to Economy

About Article

Received: 30.08.2021

Accepted: 15.12.2021

Doi: 10.18026/cbayarsos. 988518

\footnotetext{
a Dr. Öğr. Üyesi, Manisa Celal Bayar Üniversitesi, Uygulamalı Bilimler Fakültesi. ORCID:0000-0001-8592-9238

b İletişim Yazarı: nur.aydin@cbu.edu.tr

c Arş.Gör., Manisa Celal Bayar Üniversitesi, Uygulamalı Bilimler Fakültesi. ORCID:0000-0002-0943-6877
} 


\section{Giriş}

Hizmet sektörü içinde faaliyetlerini sürdüren bankalar ve finansal kuruluşlar, ekonomik bütün içinde para ve kredi piyasalarının en önemli temel taşlarını oluşturmaktadır. 1970'li yıllarda literatüre kazandırılıp 1980'li yıllardan itibaren hızla artış trendine giren küreselleşme ve finansal liberalizasyon eğilimlerinin oluşturduğu rekabet ikliminde, bankacllık ve finans sektörlerinin önemi bir kat daha fazla hissedilir hale gelmiştir. Gelişmiş ve gelişmekte olan tüm dünya ülkelerinde bankacıllk ve finans sektöründe faaliyette bulunan işletmeler, küresel finansal piyasalarda meydana gelen sürekli değişim ve finansal araçlara ilişkin artan çeşitlilikten etkilenmekte, entelektüel bilgi yönünden beşeri sermaye olarak adlandırılan kendisini yetiştirmiş nitelikli ve donanımlı personele duyulan gereksinim her geçen gün artış kaydetmektedir ( Doğan, Yorgancilar, Berkman ve Arslan, 2016).

Dünyada küreselleşme yönünde hamlelerin hissedilmeye başlandığı özellikle 1980 sonrası dönemde, kapalı ekonomi boyutundan çıkılarak İhracata Dayalı Sanayileşme Hamlesinin benimsendiği ve dışa açılım gösterildiği 24 Ocak 1980 tarihinden başlayarak, Türkiye'de bankacılık sektöründeki istihdam düzeyi, genişleme kaydetmeye başlamış ve 2000'li yıllardan itibaren bu durum daha belirgin bir şekle dönüşmüştür. 2016 yılında mali kuruluşların istihdam seviyesinin 325 bin ile toplam istihdamın yaklaşık yüzde 1,2'sine karşılık geldiği dikkate alınarak bu rakamın genel istihdam düzeyi içerisinde çok büyük olmadığı düşünülse dahi, Türkiye' de üniversite ve üzeri her 10 mezundan birisinin bankacilık ve finans alanında istihdam edildiği, bankacılık ila finans sektör çalışanlarının yüzde 50'ye yakın bir bölümünün kadınlardan oluştuğu ve Türkiye'de sorunsal olarak görülen kadın istihdamına ilişkin sektörün önemli bir yeri doldurduğu, aynı zamanda işgücüne katılım bakımından diğer bir sorunlu dilimi oluşturan eğitimli gençlerin önemli düzeyde bankacılık ve finans sektöründe istihdam imkanı bulabildiği göz önüne alındığında bankacılık ve finans sektörünün işgücü piyasasındaki önemi daha açık ve net olarak anlaşılabilmektedir (Baştürk, 2018).

Okulumuz Bankacılık ve Finans (BF) Bölümü öğrencilerinin piyasada iş bulabilme kapasitesi, iş bulabilenlerin hangi sektör/sektör alt gruplarında çalıştıklarının tespiti, işe girişte diplomaları haricinde kendilerinden istenen başkaca gerekli belge ve evraklar varsa bunların belirlenmesi, mezun öğrencilerimizin iş pozisyonlarına göre okulumuza davet edilerek seminer vb şeklinde etkinliklerle mevcut okumakta olan öğrencilerimize rol model olabilmeleri yanı sıra intörn öğrencilerimizin çalışabilecekleri iş seçeneği olabilmesi alternatifi çalışmanın ana çıtılarını oluşturmaktadır.

Bu noktada okulumuzun da bir ögesi olduğu Manisa Celal Bayar Üniversitesi (MCBÜ)'ni, Manisa ilindeki tek ve Ege Bölgesi'ndeki en büyük üçüncü üniversite olarak tanıtmak mümkündür. Çalışmamıza da temel oluşturan projeye MCBÜ Bilimsel Araştırma Projeleri (BAP) Koordinasyon Birimi tarafından onay verildiği 2019 yılını dikkate aldığımızda, aynı yıl MCBÜ'nin merkez ve ilçelerinde 15 fakülte, 2 yüksekokul, 15 meslek yüksekokulu, 3 enstitü, 28 araştırma ve uygulama merkezi olmak üzere toplam 63 birimde 55.473 öğrenciye eğitimöğretim faaliyetinde bulunduğunu ifade edebiliriz (Sofyalığlu, Kartal ve İncekırık, 2019).

\section{Literatür Taraması}

İş dünyasında olduğu kadar, günlük yaşantıda da sıklıkla kullanılan kavramlardan olan meslek ve kariyer kavramları arasında nüans farkı bulunmaktadır. Bir kimsenin eğitim yoluyla bilgi ve beceri kazanarak, diğer bireylere yararlı bir ürün/hizmet sağlamaya yönelik 
kurallarının toplumca belirlendiği etkinliklerde bulunarak hayatını devam ettirmesi meslek olarak ifade edilirken, bireyin özellikle iş ve mesleğine ilişkin rollerinde bir ömür boyu yaşadığı olaylar dizisi ve diğer yaşam rollerinin de birbirini etkilemesi ve izlemesi yoluyla meydana gelen genel örüntü ve gelişim çizgisindeki ilerleme, duraklama yada gerilemeleri de kapsayan oldukça geniş içerikteki süreç kariyer olarak tariflenmektedir (Karadeniz ve Özkan, 2021, s.115).

Kozak ve Dalkıranoğlu (2013), öğrencilik döneminden başlayarak kariyer planlamaya ilişkin çalışmaların yapılmasının mezun olunduğunda iş bulunmasını kolaylaştıracağını, çalışılacak alanla ilgili yeteneklerin geliştirilmesi ve profesyonel hayata kolayca uyum sağlama adına üniversitelerde öğrencilerin kariyer farkındalığının artırılması ve kariyer planlamasına yardımcı olunmasını, bu amaçla kariyer merkezi/ofisi kurulması, rehberlik ve danışmanlık hizmetleri verilmesi, müfredatlarda kariyerle ilgili derslere yer verilmesi ve seminerler düzenlenerek destek çalışmalarının yapılmasına işaret ettiği araştırmalarının sonucuna göre; öğrencilerin kariyer kararlarında yeterli düzeyde yönlendirme yapılmadığı, kariyer kararlarını geleneksel kalıplara göre verdikleri, maddi kaygılarının kariyer olanaklarının önünde yer aldığı, yüksek lisans yapmayı önemli bir kariyer fırsatı olarak gördükleri, kariyer siteleri hakkında bilgi sahibi oldukları ve kız öğrencilerin kariyer farkındalıklarının erkeklere göre daha yüksek olduğu ana başlıklar olarak kaydedilmektedir.

Ergincan'a göre (2010), yükseköğretim mezunlarının istihdam sorunu ve iş doyumunun çalışma hayatı ve ülke ekonomisi için önem taşıyan bir konu olduğu ileri sürülerek, gençlerin eğitimini gördükleri alanda çalışmak üzere yola çıtıkları ancak iş arama sürecine başladıktan sonra sürecin uzamasıyla karamsarlığa düştükleri, işgücü piyasasının gereksinimi olan sayı ve nitelikte elemanların yetiştirilebilmesi ve işsizliğin önüne geçilebilmesi adına ülkemizde sanayi - okul işbirliğine Avrupa'daki çoğu eğitim sisteminde olduğu gibi işlerlik kazandırılmasının gerekliliği ifade edilmiştir. Bu bağlamda söz konusu işbirliğinin etkin bir şekilde kullanılmaya başlanması ile birlikte özellikle nitelikli işsizlik konusunda bir azalma olabileceği, yeni mezun olan genç işgücünden daha efektif olarak yararlanılabileceği, bireyin sahip olduğu ve tahsil hayatında edindiği bilgi, beceri ve yetkinlikleri çalıştığı işte kullanmasının iş tatminini olumlu yönde etkilediği bildirilmiştir. Bireylerin çalışma hayatına ilişkin olarak parametrelerin sosyal ve ekonomik olarak ayrımlanabileceği vurgulanarak; özellikle ücret faktörünün, iş doyumuna etki eden ekonomik faktörlerin başında geldiği, uzmanlık alanında çalışma ve terfinin yükseköğretim mezunlarına göre iş doyumunu etkileyen diğer faktörler olduğu ileri sürülmüştür.

Yeşil ve Tokbaş'ın iddiasına göre (2018) mesleki eğitim bireyin kariyer planlamasının belirlenmesinde büyük etkiye sahip bulunmaktadır. Bu bağlamda öğrencilerin mesleki eğitimde motivasyonlarının ve beklentilerinin yüksek seviyede olmasının, öğrencilerin iş hayatına kalifiye eleman olarak daha etkin ve bilinç düzeyi yüksek bir şekilde hazırlanmalarında büyük katkı sağlayacağına işaret edilerek, mesleki eğitim faaliyetlerinin bireyin kendini geliştirmesi ve işgücü piyasasına yönelik olarak kalifiye eleman yetiştirilmesi adına büyük önem teşkil ettiği bildirilmiştir. Gençlerin okudukları bölümü sevmelerinin onların daha bilinçli ve aktif olarak meslek hayatlarında yer almalarını sağlayacağı, okudukları bölümün kendilerine gerekli imkanları sunmasının onların gelecekteki yeni fırsatları değerlendirmelerine ve istedikleri işe girmelerine imkan tanıyacağı ileri sürülerek bu manada eğitimcilerin konuya daha duyarlı yaklaşım göstermelerine vurgu yapılmaktadır. 
Erdoğan vd. (2018) Kastamonu Üniversitesi Bankacilık ve Finans bölümünde diğer üniversitelerden farklı olarak uygulanan bütünleşik müfredata dair bilgi vererek, bankacılık ve finans bölümü öğrencilerinin mezun olduklarında bankacılık, finans ve denetim sektörlerinde istihdam edilebilmesi için gerekli Kamu Gözetimi Muhasebe ve Denetim Standartları Kurumu (KGK), Sermaye Piyasası Kurulu (SPK), Türkiye Muhasebe ve Mali Müşavirler Odaları Birliği (TÜRMOB), Bankacılık Düzenleme ve Denetleme Kurumu (BDDK), Türkiye İç Denetim Enstitüsü (TIDE) Bilirkişilik ve Uzlaştırmacılık belgelerinin öğrenciler tarafından edinilebileceğini ve böylece sektörün gerektirdiği nitelikli işgücünün karşılanabileceğini öngördükleri araştırmalarında, eğitim-öğretim sürecinin ilk dört yarıyılında ortak dersler, 5nci, 6ncı ve 7nci yarıyıllarda mesleki belgelerin gerektirdiği dersler ilgili mevzuata göre düzenlenmiş müfredat (7nci yarıyıl ders, 8nci yarıyıl zorunlu mesleki uygulama) kapsamında verilerek, en az bir mesleki belge ile mezuniyet zorunluluğunun sektörün istediği mesleki belgelerin edinimlerinin mesleki uygulama ile bütünleştirilerek deneyimli mezun verilmesinin hedeflendiği, derslerde Türkiye Finansal Raporlama Standartları (TFRS) esaslı hazırlanan muhasebe ve finans ile Sermaye Piyasası Lisanslama (SPL) derslerinin okutulmasının bölüm öğrencilerine yönelik yapılan sürekli anket sonuçlarına göre, uygulanan müfredatın ve hedeflenen kazanımların 4ncü yarıyılda bulunan öğrencilerde özgüven artışını sağladığına işaret edilmektedir. Bu sayede öğrencilerin yüzde 94'ünün iş kaygısı taşımadığı, sosyal motivasyonlarının artığı ve kişisel kariyer planlamaları ile ilgili öngörülerinin netleştirildiği bilgisi verilmektedir. Gerekli yeterlilikte akademisyen eksikliği olmasına rağmen yeni kadroların açılmasının, hukuki zeminin belirlendiği "mesleki uygulama esasları" ile hazırlanmış KGK, SPK, TÜRMOB ile yapılacak protokollerin imzalanması süreçleriyle tamamlanmasının öngörüldüğ̈̈, banka çalışanlarından 29bin 786 kişinin lisans almaya hak kazandığ oranının yüzde 15.26 olduğuna işaret edilerek, uygulanmakta olan ve benzer bölümlere de uygulanması önerilen bütünleşik müfredatın öneminin çok daha fazla dikkat çektiği ifade edilmektedir. Uygulanmakta olunan bütünleşik müfredat ile sermaye piyasaları ve ekonomisi her geçen yıl büyüyen Türkiye'nin bu sektörde ihtiyaç duyacağ 1 nitelikli işgücünün yetiştirilmesine büyük katkı sağlayacağı kaydedilerek, benzer müfredat uygulayan üniversiteler arasında oluşacak etkileşim ve rekabetin işgücünün niteliğini artıracağ sonucuna varılmaktadır.

Birleşmiş Milletler (BM) ve Uluslararası Çalışma Örgütü (ILO) verilerine göre 15-24 yaş grubunda bulunan kişilerden oluşan bireyler genç nüfus olarak adlandırılmaktadır. Türkiye İstatistik Kurumu (TÜİK) verileri doğrultusunda 15-24 yaşları arasında bulunan işsizlerin genç işsiz olarak kabul edilmesi uygun olacaktır. Türkiye' de TÜİK İşgücü İstatistiklerine göre ilan edilen genç işsizliğinin yüzde 27,1 ve Ne eğitimde Ne işte olan gençlerin oranı (NEİY) ise yüzde 29,4 ile oldukça yüksek bir oranda saptanmıştır (TÜİK, 2019).

Genç işgücü potansiyeli bakımından oldukça avantajlı bir duruma sahip bulunan Türkiye'de yapılan nüfus projeksiyonları 2040 yılına kadar genç nüfus oranının azalan bir seyirde olmakla birlikte, Türkiye için bir fırsat penceresi olmaya devam edeceğini göstermektedir. Bu bağlamda Türkiye' de 2023 yılına kadar artacak olan aktif nüfusta daha büyük bir genç işsizliği ile karşılaşılmasının beraberinde genç nüfusun sahip olduğu potansiyelin kullanılamaması yanı sıra 2040 yılından sonra yaşlanan nüfusun başta sosyal güvenlik olmak üzere bazı sorunları daha da kronik hale getirmesi kaçınılmaz olarak değerlendirilmektedir. Gençlerin işgücü piyasasında karşılaştığı sorunlar nedeniyle ülkemizdeki genç işsizlik oranları birçok dünya ülkesinin genel işsizlik rakamlarından daha yüksek bir seyirde izlemektedir. 
Türkiye'de NEIYY oranının Ekonomik İşbirliği ve Kalkınma Teşkilatı (OECD) ülkeleri ile karşılaştırıldığında oldukça yüksek görüldüğü dikkat çekmektedir. OECD ülkelerinde 2015 yılı itibari ile NEIYY oranı yüzde 14,5 iken, Türkiye'de bu oran yüzde 28,8 olup, OECD ülkeleri ortalamasından yaklaşık 2 kat daha fazla bir değere sahiptir. Türkiye'nin de kurucu ülkeleri arasında yer aldığ 1 OECD verilerine göre; OECD ülkeleri ortalamasında gençlerin işgücüne katılım oranı yüzde 47.2, genç işsizlik oranı ise yüzde 12.9'dur. Türkiye, gençlerinin işgücüne katılım oranı yüzde 42,4, genç işsizlik oranı yüzde 19,6 ile OECD ülkelerine nazaran genç nüfusta daha yüksek işsizlik ve daha düşük işgücüne katılım göstergelerini sergilemektedir. 2014-2016 yılları arasında OECD ülkelerinde genç işsizliği rakamlarında yüzde 15'den yüzde 12,9'a gerileme yaşanırken bu oran Türkiye'de yüzde 17,9'dan yüzde 19,6'ya yükselme kaydetmiştir (Ümmühan, 2019, s.89).

İşgücü piyasasında, gençlerin dezavantajlı konumda olmalarına neden olan birçok parametre bulunmaktadır. Öncelikle işgücü piyasasında deneyim sahibi olmayışları, işin öğretilip eğitilme süreçleri nedeniyle işverenler tarafından işe alınmada daha maliyetli bir çalışan grubunu temsil etmelerine neden olmaktadır. Genç işsizliğinin bu denli yüksek olmasının ardında yatan unsurlar okuldan iş yaşamına geçişte karşılaşılan sorunlar üzerine odaklanmaktadır. Eğitimini aldıkları alanda çalışma imkanı bulamayışları işsizliğin nicel görünümünün yanı sıra niteliksel boyutlarını da ortaya koymakta ve eksik istihdam boyutuna dair çalışmalar yapılmasını gerektirmektedir. Türkiye' de yükseköğrenim ve lisansüstü eğitim programları mezunlarının da durumlarının ele alınıp değerlendirilmesinin gerekliliği, genç işsizliği oranlarındaki bu denli yüksekliği irdeleyebilmek için akla gelen bir başka konu başlığıdır. Dördüncü Sanayi Devrimi olarak da adlandırılan Endüstri 4.0`ın baş döndürücü etkisiyle bilim, teknoloji ve yenilikçi üretim alanlarında büyük gelişme ve değişim yaşanmaktadır. Uluslararası rekabet gücünün yükselebilmesi için kalifikasyonu yükseltilmiş işgücüne ihtiyaç bulunmaktadır. Dünya Rekabet Endeksi (WEF) sıralamasına göre 141 ülke arasında Türkiye 61nci sırada yerini almaktadır. İşsizlik ve nitelikli işgücü sorunları yanı sıra Araştırma Geliştirme (AR-GE) yatırımlarındaki yetersizlik, daha üst basamaklara gelinmesinde başlıca engeller olarak belirtilmektedir. Zira Türkiye işgücü piyasası bileşeninde 109ncu sırada, beceriler bileşeninde 78nci sırada olarak kaydedilmektedir (WEF, 2019).

İşücü piyasasının karakteristik özellikleri, işgücünün nitelikleri ve nitelikli insan kaynağının istihdamı sıralamadaki yerleri belirleyen en önemli parametreler olarak dikkat çekmektedir. Mezun ve işgücü piyasası arasındaki dengesiz korelasyon, bu ilişkide önemli bir etmen olan nitelik uyumsuzluğu şeklinde ifade edilmektedir (Çakır ve Kellevezir, 2020, s.1).

Durkaya ve Hüsnüoğlu'na göre (2018) eğitim; verimlilik, üretim ve gelir artışı üzerinde etkili olan uluslararası rekabetin en önemli parametrelerinden birisidir. Eğitim sayesinde beşeri sermayenin donanımının güçlendirilerek işgücünün bilgi, beceri, yetenek ve niteliklerinin artırılması sağlanmaktadır. Ekonomik büyüme ve refah artışının olumlu ivme kazanıp işgücüne katılım oranı ve ücret seviyelerinin artmasına imkan kılan eğitimin, teknolojik ilerleme ve yeniliklerin de öncüsü olduğunun altı çizilmektedir. Eğitimin istihdamdaki rolünün Türkiye ve farklı gelişmişlik düzeylerine sahip ülkeler açısından analiz edildiği çalışmada, Türkiye'de lise altı eğitimlilerin en fazla istihdam oranına sahip olduğu, eğitim düzeyindeki yükselmelerin kazançları ve işgücüne katılım oranını artırdığı, ülkeler yönünden incelendiğinde eğitim düzeyindeki ilerlemenin insani gelişime pozitif yansıdı̆̆ı, eğitim alanındaki olumlu gelişmelerin kişi başına düşen gelir, ücretler, emek verimliliği ve teknoloji 
seviyesindeki artışları da beraberinde getirdiği, eğitim seviyesi artan kadın bireylerin işgücüne katılımlarının da arttığı dile getirilmektedir.

Doğan vd'nin (2016) çalışmasına göre, yükseköğretim kurumlarında lisans düzeyinde verilen bankacılık ve finans eğitim-öğretiminin sektörün beklentilerini ne düzeyde karşıladığ1 ölçülmüştür. Sektörde çalışmaya aday mezunların sahip olması gereken temel nitelikler ile ilgili bir değerlendirmede bulunularak, Niğde, Konya ve Kayseri illerindeki bankacılık ve finans kuruluşlarının üst düzey yöneticileri ile yüz yüze mülakat ve anket yoluyla saha araştırması yapılmış; bankacılık ve finans bölümü lisans eğitiminin ders içerik ve öğretim metotları tartışılmış, lisans düzeyi derslerinin sektör talebi ile uyumlu kılınması için bazı öneriler getirilmiştir. Küreselleşmenin de etkisiyle finansal piyasalarda meydana gelen sürekli değişim ve gelişim sonucunda bankacılık ve finansal ürünlerinde çeşitlilik ve artışın gerçekleştiği, sektörde yaşanan bu gelişmelerin beraberinde Türkiye gibi gelişmekte olan ekonomilerde sektörün özellikle kalifiye elemana olan ihtiyacının ön plana çıktığı, birçok banka veya finansal kurumun ileride yönetici statüsünde görevlendireceği kişileri kurum içerisinden seçmeye özen gösterdiği ve geleceğin yöneticileri olabilecek çalışanların işgücü piyasasına kazandırılması noktasında yükseköğretim kurumlarının önemli derecede katkıları bulunduğu kaydedilmektedir.

Selim vd (2020), bilgi ve teknolojinin hakim olduğu ve bilginin güç olarak algılandığ1 günümüz dünyasında, bilginin ve bilimin üretildiği yerler olan yükseköğretim kurumlarına karşı talep artışı yaşandığı, yükseköğretim kurumlarına karşı duyulan talep artışı ile yeni yatırımların gerçekleştirilmesinin gündeme geldiği, bu manada yapılan yatırımların ne derece etkin kullanıldığının tespit edilmesi adına yükseköğretimde performans değerlendirmesinin 2015 yılı baz alınarak Veri Zarflama Analizi (VZA) ile gerçekleştirildiği çalışmalarında; 25 OECD ülkesi ve eğitime yönelik iki farklı veri kümesi ile sırasıyla 24 ve 25 OECD ülkesi benzer girdi kullanan ve çıktı üreten karar verme birimi olarak belirlenerek, akademik performans ve eğitime yönelik etkinlikleri analiz edilmiştir. Türkiye'nin en düşük etkinliğe sahip ülkeler arasında yer aldığ 1 bildirilen araştırma sonucuna göre; analizlerde etkin bulunan ülkeler sırasıyla Finlandiya, İrlanda ve Slovenya olarak bildirilmektedir.

Sarıgül (2013) küresel ekonomik gelişme ile birlikte finansal ortamdaki hızlı değişim ve gelişimlerin yanı sıra demografik değişikliklerin, kapsamlı ve kaliteli düzeyde bankacılık ve finans uygulamalarının önemini artırdığını vurgulayan çalışmasında, eğitim ile teorik bilgi ve temel ilkelerin öğretildiği, finansal hizmet sektörlerinde birçok uluslararası ve yerel standart ile düzenlemelerin uygulandığ uygulamalı bilimler alanında olan bankacılık ve finansın bilgi birikiminin yanı sıra beceri geliştirmeyi de gerekli kıldığı, Türkiye'de bankacılık ve finans eğitiminin, meslek liseleri, üniversiteler ve bankaların ilgili bölümlerinde intörn şeklinde işbaşı uygulaması ile yapılabildiği, üniversitelerin çoğunun iktisat ve işletme-yönetim fakültelerini içerdiği, bankacılık ve finans üzerine bazı kurslar verildiği ifade edilerek sadece 19 fakülte veya uygulamalı bilimler fakültesinde bankacılık ve finans eğitimi üzerine lisans derecesinde eğitim öğretim sunulduğu bildirilmiştir.

Duramaz (2018) Ege Bölgesi'nde yer alan Kütahya Dumlupınar Üniversitesi, Uşak Üniversitesi ve Manisa Celal Bayar Üniversitesi Uygulamalı Bilimler Yüksekokulları bünyesinde eğitim veren "Bankacılık ve Finans" bölümlerinin etkinlik analizlerini veri zarflama analizi ile test ettiği çalışmasında, 2017 yılına ait veriler ele alınarak seçilen girdi ve çıktı parametreleri kapsamında değerlendirmede bulunmuştur. Araştırma sonuçlarına göre; 
Uşak Üniversitesi Bankacılık ve Finans Bölümü ile Manisa Celal Bayar Üniversitesi Bankacılık ve Finans Bölümlerinin etkinlik düzeyinin tam etkin seviyesinde olduğu kaydedilerek, Kütahya Dumlupınar Üniversitesinin Bankacılık ve Finans bölümünün tam etkinlik düzeyine yakın bir değere sahip olsa da diğer üniversitelere göre nispi olarak daha az etkin olduğu ve tam etkinlik düzeyine ulaşabilmesi için bölüm akademik personelinin yayın sayısının arttırılması yanı sıra öğrenci sayısının da kısmen azaltılması gerekliliğine vurgu yapılmıştır.

İbiş ve Çelikdemir (2011) bankacılık sektörünün muhasebe eğitiminden beklentileri konusunda yaptıkları saha çalışmasında, 32 bankanın muhasebeden sorumlu müdür yardımcılarına anket gerçekleştirmişlerdir. Araştırma sonucuna göre; teorik bilgilerle ilgili beklentilerin karşılandığı belirtilmekte fakat pratik eğitimin geliştirilmesi için üniversite ve bankaların iş birliği yapması gerekliliğinin altı çizilmektedir.

Delikanlı (2011), "Banka Dışı Finansal Kuruluşlarda Günlük Finansal Raporlama Faaliyetlerinin Kapsamı, Organizasyonel Yapısı ve Muhasebe Eğitiminden Beklentiler" başlığını taşıyan çalışmasında, ilgili kuruluşların kamuya hesap verme yükümlülüğü ve finansal raporlama uygulamalarının Türkiye Muhasebe Standartları (TMS) ile Uluslar arası Muhasebe Standartları (UMS) ve Türkiye Finansal Raporlama Standartları (TFRS) ile Uluslar arası Finansal Raporlama Standartları (UFRS) doğrultusunda gerçekleştirilmesi gerektiği belirtilerek, üniversitelerde uluslararası standartları konu edinen seçmeli derslerin konulmasina dair beklentiler dile getirilmektedir.

Reedvd (2009) bankacılık sektörünün yeniliğe ve değişime son derece açık olduğu, teknolojinin yoğun olarak kullanıldığı, iletişimin son derece önemli olduğu, göreceli olarak iyi bir sosyal statü sağladığı, çalışanları mesleki açıdan sürekli kendini geliştirmeye sevk ettiği, çoğunlukla stresli ve yoğun bir çalışma temposunun geçerli olduğu ve çalışanların eğitim düzeyleri ile mesleki niteliklerinin büyük önem arz ettiği belirtilmektedir. Beşeri sermaye olarak da adlandırılan işgücünün niteliğinin bankaların faaliyet sonuçlarını önemli ölçüde etkileyebildiği, işgücünün yetenekleri ve birikim düzeyi ile bankaların finansal performansları arasında güçlü bir korelasyon olduğu bildirilmektedir.

Sarkis (1999), Teknolojinin yoğun olarak kullanıldığı bir sektör olan bankacılık sektörünün teknolojide yaşanan gelişmeler doğrultusunda istihdam hacminin olumsuz düzeyde etkilendiği belirtilerek, sıkı rekabet koşulları ve önemi hızla artan risk unsurlarına dayalı bir şekilde sektörün hızla genişlediği, kendi içinde çeşitlilik arz eden hizmet alanlarına göre yenilenen iş tanımları içerdiği ifade edilmiştir. Bu bağlamda 2000'li yılların başında bankaların risk yönetimi ve iç denetim işlevlerinin ayrı birer birim haline getirilmesi örneklenerek müşteri beklentilerindeki artış unsurlarının istihdam hacmine olumlu katkılarda bulunduğu kaleme alınmaktadır.

Acaray ve Pelenk (2018), Recep Tayyip Erdoğan Üniversitesi Fındıklı Uygulamalı Bilimler Yüksekokulu Bankacılık ve Finans bölümü öğrencilerinin bankacılık ve finans sektöründe yaptıkları yaz dönemi stajlarını inceledikleri araştırmalarında, yaş ortalaması 21,48 olan örneklemin yüzde 67'sinin kız, yüzde 33'ünün erkek öğrencilerden olmak üzere toplamda 75 öğrenciden oluştuğu belirtilmiştir. 2017 yaz döneminde gerçekleşen toplam 40 işgünü süren staj yerlerinin penetrasyonuna bakıldığında; yüzde 72'sinin özel bankalarda, yüzde 24'ünün kamu bankalarında, yüzde 4'ünün banka dışı diğer finans kurumlarında olduğuna dikkat çekilmektedir. Stajyer çalışanların mesleki bağlılıklarının gelişiminde önemli bir ayrıcalığa sahip olduğu ifade edilen ve uygulanan farklı iş uygulamalarından dolayı örgütte özel bir durum olan, iş gören algılamalarının ve davranışlarının değişimi üzerinde önemli bir 
fonksiyon ortaya koyan örgüt iklimi üzerine odaklanılan çalışmanın temel amacı, örgüt ikliminin mesleki bağlllık üzerindeki etkisini irdelemektir. Araştırmadan elde edilen verilerle, staj yapan öğrencilerin çalıştıkları kurumların yönetsel destek, yönetim yeteneği ve tutarlılığı, iş yükü, organizasyonel kısıtlar, çalışanların uyum ve birlikteliği ve etik iklim boyutlarına ilişkin algılamalarının mesleğe olan bağlılıklarını pozitif ve anlamlı olarak etkilediği ortaya konulmaktadır. Bu bağlamda öğrencilerin mezun olduklarında staj dönemlerinde çalıştıkları kurumların iklimlerinin pozitif olarak algılanmasının mesleğe bağlılıklarını sağlayan parametrelerin başında geldiği anlaşılmaktadır. Banka ve finans sektöründe geleceğin meslek çalışanları olarak stajyer öğrencileri konumlandırdığımızda, ilgili kurumların insan kaynakları uygulamalarının açık, şeffaf ve adil olarak gerçekleştirilmesi gerektiği düşünülmektedir. Stajyer çalışanların bağımsız ve bağımlı değişkenleri algılamaları bakımından konu değerlendirildiğinde; örgüt iklimi boyutlarından sırasıyla en çok etik iklim, yönetimin yeteneği ve tutarlılığı ile organizasyonel kısıtların pozitif algılamaya sahip olduğu görülmektedir. Mesleki bağlllık parametresi, tüm parametreler içerisinde en düşük ortalamaya sahip olarak bulunmuştur. Örgüt iklimi algılamalarının daha yüksek oranda pozitif olmasına rağmen mesleki bağlılığın göreceli olarak düşük çıkmasını staj yapan öğrencilerin sektörde çalışmak istemediği şeklinde yorumlanmaktadır.

Uygulamalı Bilimler Yüksekokulu Bankacılık ve Finans Bölümü lisans öğrencilerinin mezuniyetlerinde iş bulabilme kapasiteleri ve iş doyumları üzerinde daha önce yapılan bir çalışmaya rastlanılamamıştır. Muhasebe, turizm ve girişimcilik vb diğer alanlardaki çalışmalar dikkat çekmiştir. Bu itibarla öncelikle bu çalışma ile, yazın alanında bir katkı sağlanmış olacaktır. Ayrıca bölüm öğrencilerimizin sahada başarı durumları tespit edilmeye çalışılarak, bölümü yeni seçmeye aday öğrencilere de katkı sağlanması çalışmanın özgün başlıklarını oluşturmaktadır.

\section{Yöntem}

\section{Araştırmanın Amacı}

Bu araştırma ile Uygulamalı Bilimler Yüksekokulu Bankacılık ve Finans Bölüm mezunu öğrencilerimizin tamamına erişilerek istihdam düzeylerinin tespit edilmesi ile ekonomiye katkılarının ortaya konulabilmesi yanısıra elde edilen çıktılar yoluyla henüz eğitimine devam eden öğrencilerimize de yol haritası oluşturulmasına çalışılmıştır.

\section{Araştırmanın Konu ve Kapsamı}

Araştırmanın konusu, bankacılık ve finans bölümü mezunu öğrencilerimizin diğer aynı bölüm öğrencilerine nazaran iş bulabilmelerinde avantajlı olup olmadıkları, lisans eğitimini aldıkları alanda mı yoksa başka bir alanda $\mathrm{m} ı$ istihdam edilebilme imkanları, aldıkları eğitimöğretimin devamında iş olanakları için Sermaye Piyasası Lisanslama (SPL) belgeleri yanısıra ve/veya başkaca belgelerin gerekli olup olmadığının belirlenmesi, mezunlarımızın bölümü seçmekle mutluluk düzeylerinin tespiti, mezun takibinin yapılarak oluşturulacak sinerji ile mezunlarımız arasında kurumsal bağlılık oluşturulmaya çalışılması, mezunlarımızın okulumuza davet edilerek bilgi, tecrübe ve birikimlerini öğrencilerimizle paylaşmalarının sağlanması hedeflenmiştir.

Araştırmanın konusu doğrultusunda benzer ulusal çalışmalardan derlenen bir anket formu hazırlanmıştır. Ankette araştırmanın ana kütlesi içinde yer alan öğrencilerin demografik 
özelliklerinin tanımlanması (cinsiyet, yaş, eğitim durumu, iş durumu, çalıştığ1 sektör, iş yerindeki statüsü, ortalama aylık gelir ve Bankacılık ve Finans (BF ile ilgili bir sektörde çalışıp çalışmadığı), eğitim/öğrenim (mezuniyet yılı, başarı düzeyi, yabancı dil bilgisi ve düzeyi, üniversitede kazandığı deneyimler) ile kariyerlerine yönelik (kariyerleri boyunca iş değiştirme sayısı, bölümün kariyerlerine katkısı, kariyer kaynakları, kariyer kaynağı olarak kullanılan internet siteleri ile meslek fuarlarının kariyerlerine katkısı ve BF mezunu olmaktan duyulan memnuniyet) hakkında sorular sorulmuştur. Son olarak, açık uçlu sorulan ve BF ile ilgili sektörlerde çalışan öğrencilerin işe giriş ve yükselmek için istenen belgelerin neler olduğu ile bölümde eğitim öğretim kalitesinin artırılması için getirilen öneri ve görüşler listelenmiştir. Ankette yer alan ifadelerin dağılımlarını incelemek için frekans analizleri yapılmıştır. Tüm analizler SPSS 16.0 paket programında işlenerek, literatüre ve ilgilenenlere faydalı olunması amaçlanmıştır.

\section{Evren ve Örneklem}

Araştırmanın ana kütlesi, Manisa Celal Bayar Üniversitesi Uygulamalı Bilimler Yüksekokulu Bankacılık ve Finans Bölümünün mezun öğrencilerinden oluşmaktadır. Yaklaşık olarak 1.760 kişi olduğu öğrenilen ana kütle evrenine; telefon, e-mail ve ikametgah bilgileri yoluyla yapılacak güncellemelerle Google formlardan yararlanılarak anket yoluyla ulaşılmaya çalışılmıştır.

Araştırmanın hedef kitlesi olan mezun öğrencilerimize ulaşabilmek adına öğrencilerin en kapsamlı listesine sahip Bilgi İşlem Araştırma Uygulama Merkezi (BAUM)'nden temin edilen liste kullanılmıştır. BAUM'dan okulumuz Bankacılık ve Finans Bölümünün 2006 yılında ilk mezunlarını verdiği dönemden araştırmamızın özünü oluşturan projemize onay verildiği tarihe değin (Mayıs/2019), yaklaşık toplam 1.760 mezun öğrencimize dair Excel formatındaki liste temin edilmiştir. Liste incelendiğinde araştırma kapsamındaki hedef kitlenin coğrafi bakımdan dağınık bir yapı sergilediği görülmüştür.

Listenin kapsamlı bir şekilde incelenmesi neticesinde; Okulumuz Bankacılık Finans Bölümünden ilk mezunların 28/06/2006 tarihinde verildiği, mezun öğrencilerin önemli bir kısmının @cbu.edu.tr uzantılı mail adresleri dışında güncel mail adresi veya telefonları olmadığı, iletişim kanalı olarak genellikle ikametgah adreslerinin yer aldığı tespit edilmiştir.

Hedef kitleyi oluşturan 1.760 öğrencimizin ikametgah adreslerine posta yoluyla anket formlarının gönderilmesinin oldukça yüksek maliyete ulaşacağı hesaplanmıştır. Bu hususlar dikkate alındığında gerek maliyet gerekse postanın zamansal olarak gidiş dönüşü ile alakalı sürenin uzunluğu gibi kısıtlar nedeniyle anketin internet aracılığılla yapılmasına karar verilmiştir.

Maliyet ve zaman parametrelerinin etkisiyle, BAUM'un listesindeki e-mail adresi ve/veya telefon numarası bulunduğundan iletişimin daha rahat olabileceği düşünüldügüunden örneklem olarak seçilen yaklaşık 500 öğrenciye araştırma konusu anket soruları e-mail yoluyla gönderilmiş ve anket sorularının eksiksiz bir şekilde cevaplanması istenilmiştir. Dönüş sayısının çok düşük kalması nedeniyle düzenli olarak hatırlatma e-mailleri gönderilmeye devam edilmiştir.

Araştırmamıza baz oluşturan projenin ilgili sürelerinin sonuna yaklaşıldığında, sınırlı dönüş oranı olduğu görülerek listede bulunan öğrencilere telefon yoluyla ulaşılmış ve anket linkinin 
de gönderilmesiyle çalışmaya katkı sağlamaları istenmiştir. Tüm bu çalışmalar sonucunda 216'sı kullanılabilir olmak üzere toplamda 234 anketin geri dönüşü sağlanmıştır. 18 anketin kullanılamama nedeni ise sorulara eksik cevap vermelerinden kaynaklanmıştır. İstatistiksel tekniklerin kullanılabilmesi için 30'dan büyük, 500'den küçük örnek büyüklüklerinin birçok araştırma için yeterli olduğu kabul edilmektedir (Altunışık, Coşkun, Bayraktaroğlu ve Yildırım, 2010, s.134-135).

\section{Materyal ve Yöntem}

Araştırma sonucu örneklem kitleden anket formları yoluyla bilgisayar ortamında elde edilen veriler, SPSS paket programında işlenmiştir. Anket sorularına verilen yanıtların dağılımında frekans analizleri kullanılmıştır.

\section{Bulgular}

Bu bölümde araştırma kapsamında elde edilen bulgulara yer verilmiştir.

\section{Araştırmaya Katılanların Demografik Özellikleri Bakımından Analizi}

Tablo 1 incelendiğinde, cinsiyet değişkenine göre, araştırmaya katılan kişilerin 88'inin erkek $(\% 40,7), 128$ 'inin $(\% 59,3)$ kadın katılımclardan oluştuğu görülmektedir. Medeni durum açısından 140 kişi $(\% 64,8)$ bekar iken, 76 'sı $(\% 35,2)$ evlidir. Araştırmaya katılan kişilerin yüzde 45.4'ünün (98 kişi) 27-30 yaş aralığında, yüzde 43.1'inin (93 kişi) 23-26 yaş aralığında, yüzde 8.8'inin (19 kişi) 30 yaşından büyük ve yüzde 2.8'i oluşturan 6 kişinin 23 yaşından küçük olduğu saptanmıştır. Eğitim durumu değişkenine göre araştırmaya katılan kişilerin büyük bir bölümünün (193kişi; \%89,4) lisans mezunu oldukları, 21 kişinin yüksek lisans (\%9,7), 2 kişinin de $(\% 0,9)$ doktora yaptığ 1 anlaşılmaktadır. İş durumu değişkenine göre araştırmaya katılan kişilerden 181'i (\%83,8) çalışırken, 35 kişinin (\%16,2) çalışmadığı görülmektedir. Çalışan 181 kişinin çalıştı̆̆ 1 sektörlere göre dağılımları incelendiğinde, 114'ünün (\%63.0) özel sektör ve 59 'unun $(\% 32,6)$ kamu sektöründe çalıştığı, $8^{\prime}$ inin $(\% 4,4)$ ise kendi işini kurduğu tespit edilmiştir. Çalışan kişilerin istihdam edildikleri iş yerlerindeki statüleri bakımından büyük bir bölümünün (91 kişi; \%50,3) memur olduğu, 40 kişinin (\%22,1) orta kademe yönetici, 38 kişinin $(\% 21,0)$ işçi ve 10 kişinin $(\% 5,5)$ ise üst kademe yönetici oldukları görülmektedir. Araştırmaya katılan kişilerin iş yerlerindeki statüleri bakımından akademik personel olmalarına göre de bir ayrıma gidilmiştir. Buna göre 2 kişinin (\%1,1)akademik personel olarak görev yaptıkları anlaşılmıştır. Araştırmaya katılan mezun öğrencilerin büyük bir bölümü, ortalama aylık gelir açısından (122 kişi; \%67,4) 4.000 TL'nin altında bir gelire sahipken, 40'1 4.000-5.500 TL (\%22,1), 13'ü 5.501- 7.000 TL $(\% 7,2)$ ve sadece 6's1 $(\% 3,3) 7.000$ TL'nin üstünde gelir elde ettiğini bildirmiştir. Son olarak araştırmaya katılan ve çalışma hayatında olan 181 kişiden 95' i $(\% 52,5)$ eğitimini aldıkları bankacılık ve finansla ilgili sektörlerde çalışırken 86 'sının $(\% 47,5)$ diğer sektörlerde çalıştığı saptanmıştır. 
Tablo 1. Katılan Mezun Öğrencilerin Demografik Özelliklerinin Dağılımı

\begin{tabular}{|c|c|c|c|c|c|}
\hline \multicolumn{3}{|c|}{ Cinsiyet } & \multicolumn{3}{|c|}{ Çalıştığı Sektör (Çalışan) } \\
\hline Erkek & 88 & $\% 40.7$ & Özel Sektör & 114 & $\% 63,0$ \\
\hline Kadın & 128 & $\% 59.3$ & Kamu Sektörü & 59 & $\% 32,6$ \\
\hline \multirow{2}{*}{ Toplam } & \multirow{2}{*}{216} & \multirow{2}{*}{$\% 100$} & Kendi İşi & 8 & $\% 4,4$ \\
\hline & & & Toplam & 181 & $\% 100$ \\
\hline \multicolumn{3}{|c|}{ Medeni Durum } & \multicolumn{3}{|c|}{ İşyerindeki Statüsü(Çalışan) } \\
\hline Bekar & 140 & $\% 64.8$ & Üst Kademe Yönetici & 10 & $\% 5,5$ \\
\hline Evli & 76 & $\% 35.2$ & Orta Kademe Yönetici & 40 & $\% 22,1$ \\
\hline \multicolumn{3}{|c|}{ Eğitim Durumu } & Memur & 91 & $\% 50,3$ \\
\hline Lisans & 193 & $\% 89.4$ & İşçi & 38 & $\% 21$ \\
\hline Yüksek Lisans & 21 & $\% .9,7$ & Akademisyen & 2 & $\% 1,1$ \\
\hline Doktora & 2 & $\% 0,9$ & Toplam & 181 & $\% 100$ \\
\hline \multirow{2}{*}{\multicolumn{3}{|c|}{ Yaş }} & \multicolumn{3}{|c|}{ Ortalama Aylık Gelir(Çalışan) } \\
\hline & & & 4000 TL'den az & 122 & $\% 67,4$ \\
\hline 23'tenküçük & 6 & $\% 2,8$ & $4000-5500 \mathrm{TL}$ & 40 & $\% 22,1$ \\
\hline $23-26$ & 93 & $\% 43,1$ & 5501-7000 TL & 13 & $\% 7,2$ \\
\hline $27-30$ & 98 & $\% 45,4$ & 7000 TL'den fazla & 6 & $\% 3,3$ \\
\hline 30'dan büyük & 19 & $\% 8,8$ & Toplam & 181 & $\% 100$ \\
\hline \multicolumn{3}{|c|}{ İş Durumu } & \multicolumn{3}{|c|}{$\begin{array}{c}\text { Bankacılık ve Finansla İlgili Sektörlerde } \\
\text { Çalışanlar (Çalışan) }\end{array}$} \\
\hline Çalışan & 181 & $\% 83.8$ & Bankacılık ve Finans & 95 & $\% 52,5$ \\
\hline Çalışmayan & 35 & $\% 16.2$ & Diğer & 86 & $\% 47,5$ \\
\hline Toplam & 216 & $\% 100$ & Toplam & 181 & $\% 100$ \\
\hline
\end{tabular}

\section{Araştırmaya Katılanların İş Durumunun Cinsiyet Değişkenine Göre İncelenmesi}

Cinsiyet Değişkenine Göre Araştırmaya Katılanların İş Durumu Bakımından Dağılımlarını gösteren Tablo 2 ve Cinsiyet Değişkenine Göre Araştırmaya Katılan Öğrencilerin BF ile İlgili Sekörlerde Çalışmaları Bakımından Dağılımlarını gösteren Tablo 3 bir arada değerlendirildiğinde; çalışma hayatında olan 181 kişinin 79'unun erkek, 102'sinin kadın bireylerden oluştuğu ve erkeklerin yaklaşık yüzde 42'sini oluşturan 33 kişinin tahsilini gördükleri bankacılık ve finans alanında çalışırken, bu oranın kadınlarda \%60'a çımakta olduğu (61 kişi) görülmektedir.

Tablo 2. Cinsiyet Değişkenine Göre Araştırmaya Katılanların İş Durumu Bakımından Dağılımları

\begin{tabular}{|c|c|c|}
\hline & Çalışıyor & Çalışmıyor \\
\hline Erkek & 79 & 9 \\
\hline Kadın & 102 & 26 \\
\hline Toplam & 181 & 35 \\
\hline
\end{tabular}


Tablo 3. Cinsiyet Değişkenine Göre Araştırmaya Katılan Öğrencilerin BF ile İlgili Sektörlerde Çalışmaları Bakımından Dağılımları

\begin{tabular}{c|c|c|c} 
Cinsiyet & $\begin{array}{c}\text { Bankacılık } \\
\text { ve Finans }\end{array}$ & Diğer & Toplam \\
\hline Erkek & $33(\% 42)$ & $46(\% 58)$ & 79 \\
\hline Kadın & $61(\% 60)$ & $41(\% 40)$ & 102 \\
\hline Toplam & $\mathbf{9 4}(\% \mathbf{5 2})$ & $\mathbf{8 7}(\% \mathbf{4 8})$ & $\mathbf{1 8 1}$ \\
\hline
\end{tabular}

\section{Araştırmaya Katılanların Ĕ̆itim ve Öğretim Bilgileri Yönünden İncelenmesi}

Araştırmaya katılanları eğitim ve öğretim bilgileri yönünden inceleyen Tablo 4'de; araştırmaya 2009, 2010 ve 2011 yıllarından sadece 3'er kişinin katıldığı, büyük bir bölümünün ise 2012 yılı sonrasındaki mezunlardan oluştuğu görülmektedir. Bu durum öğrencilerin zamanla iletişim adreslerini değiştirdikleri anlamına gelebilir. Araştırma kapsamında değerlendirilen kişilerin üniversitedeki başarı düzeyi bakımından 154 kişinin $(\% 7,3)$ kendini başarılı, 30 kişinin başarısız $(\% 13,9), 32$ kişinin ise $(\% 14,8)$ vasat buldukları anlaşılmaktadır. Araştırmada öğrencilerin yabancı dil bilgisi ve düzeyi hakkında da bilgiler istenmiştir. Buna göre araştırmaya katılan 178 kişi $(\% 82,4)$ en azından bir yabancı dil bildiklerini, 38 kişi ise $(\% 17,6)$ yabancı dil bilmediklerini ifade etmişlerdir. Diğer taraftan yabancı dil bilen kişilerden sadece 7'sinin $(\% 3,9)$ yabancı dil düzeyinin çok iyi olduğu, 59 kişinin $(\% 33,1)$ iyi ve 112 kişinin ise $(\% 62,9)$ orta düzeyde olduğu anlaşılmaktadır. Öğrencilerin üniversitede kazandığ deneyimler açısından dağılımları incelendiğinde; 95 kişinin (\%44) iş alanı ile olan çalışmalardan, 70 kişinin $(\% 32,4)$ ise sosyal ve kültürel etkinliklere katılımdan faydalandıkları görülmektedir. Bu anlamda üniversitenin öğrencilere büyük katkı sağladığı söylenebilir. Diğer taraftan 9 kişi $(\% 4,2)$ alan dışı uygulamalara katılmaktan, 4 kişi $(\% 1,9)$ ise yabancı bir ülkede öğrenim ve çalışma bakımından deneyim elde ettiklerini belirtmiştir. Kalan 38 kişi ise $(\% 17,6)$ belirtilen değişkenlerden hiç birinden herhangi bir deneyim kazanmadıklarını bildirmiştir.

Tablo 4. Katılan Mezun Öğrencilerin Eğitim-Öğretim Bilgileri Yönünden Dağılımı

\begin{tabular}{|c|c|c|c|c|c|}
\hline \multicolumn{3}{|c|}{ Mezuniyet Yilı } & \multicolumn{3}{|c|}{ Yabancı Dil Bilgisi } \\
\hline 2009 & 3 & $\% 1,4$ & Evet & 178 & $\% 82,4$ \\
\hline 2010 & 3 & $\% 1,4$ & Hayır & 38 & $\% 32,6$ \\
\hline 2011 & 3 & $\% 1,4$ & Toplam & 216 & $\% 100$ \\
\hline 2012 & 20 & $\% 9,3$ & & & \\
\hline 2013 & 28 & $\% 13,0$ & \multicolumn{3}{|c|}{ Yabancı Dil Düzeyi } \\
\hline 2014 & 28 & $\% 13,0$ & Çok iyi & 7 & $\% 3,9$ \\
\hline 2015 & 25 & $\% 11,6$ & İyi & 59 & $\% 33,1$ \\
\hline 2016 & 28 & $\% 13,0$ & Orta & 112 & $\% 62,9$ \\
\hline 2017 & 34 & $\% 15,7$ & Toplam & 178 & $\% 100$ \\
\hline 2018 & 30 & $\% 13,9$ & \multicolumn{3}{|c|}{ Üniversitede Kazanılan Deneyimler } \\
\hline 2019 & 14 & $\% 6,5$ & $\begin{array}{l}\text { İş alanı } \\
\text { calıșma }\end{array}$ & 95 & $\% 44$ \\
\hline
\end{tabular}




\begin{tabular}{lcc|lcc}
\hline Toplam & $\mathbf{2 1 6}$ & $\mathbf{1 0 0 , 0}$ & $\begin{array}{l}\text { Alan dişı uygulamalara } \\
\text { katılım }\end{array}$ & 9 & \%4,2 \\
\hline Başarı Düzeyi & & $\begin{array}{l}\text { Sosyal ve kültürel } \\
\text { etkinliklere } \\
\text { katılım }\end{array}$ & 70 & $\% 32,4$ \\
\hline Başarılı & 154 & $\% 71,3$ & $\begin{array}{l}\text { Yabancı bir ülkede } \\
\text { Öğrenim ve çalışma }\end{array}$ & 4 & $\% 1,9$ \\
\hline Başarısız & 30 & $\% 13,9$ & Hiç biri & 38 & $\% 17,6$ \\
\hline Vasat & 32 & $\% 14,8$ & Toplam & 216 & $\% 100$ \\
\hline Toplam & $\mathbf{2 1 6}$ & $\mathbf{\% 1 0 0}$ & & & \\
\hline
\end{tabular}

Araştırmaya Katılan Kişilerin Kariyerleri Boyunca İş Değiştirme Sayıları Bakımından Incelenmesi

Tablo 5 incelendiğinde araştırmaya katılanlardan 98' inin $(\% 45,4)$ çalışmaya başladıkları yıldan itibaren hiç iş değiştirmemiş kişilerden oluştuğu, 3 ve 3 'ten fazla iş değiş̧irenlerin sayısının 29 $(\% 13,4)$, bir kere iş değiştirenlerin 34 kişi $(\% 15,7), 2$ kere iş değiştirenlerin 30 kişi $(\% 13,9)$ olduğu araştırmaya katılan 25 kişinin ise mezun olduktan sonra hiç çalışmadığı öğrenilmiştir.

Tablo 5. Araştırmaya Katılan Mezun Öğrencilerin Kariyerleri Boyunca İş Değiştirme Sayıları Bakımından Dağılımları

\begin{tabular}{lcc}
\hline Hiç çalışmadım & 25 & $\% 11,6$ \\
\hline Hiç değiştirmedim & 98 & $\% 45,4$ \\
\hline 1 & 34 & $\% 15,7$ \\
\hline 2 & 30 & $\% 13,9$ \\
\hline 3 & 15 & $\% 6,9$ \\
\hline 3'ten fazla & 14 & $\% 6,5$ \\
\hline Toplam & $\mathbf{2 1 6}$ & $\mathbf{\% 1 0 0 , 0}$ \\
\hline
\end{tabular}

\section{Araştırmaya Katılan Kişilerin Kariyer Kaynaklarn Bakımından İncelenmesi}

Kariyer kaynakları bakımından sorulan soruları, araştırmaya katılan ve çalışan 181 kişiden 66'sı (\%36,5) kariyer sitelerinden yararlandıklarını bildirerek yanıtlamıştır. 41 kişi $(\% 22,7)$ arkadaş ve/veya tanıdık, 43'ü (\%23,8) işveren web sitesi, 22'si $(\% 12,2)$ işverenle şahsen irtibat kurarak, $4^{\prime}$ ü $(\% 2,2)$ işveren tanıtım standları ve 5'i de (\%2,8) intörn staj programlarının kariyer kaynağı olduğunu belirtmişlerdir. Araştırmada ayrıca kariyer kaynağı olarak kariyer sitelerini seçen katılımcıların hangi sitelerinden yararlandıkları da sorulmuştur (Tablo 6). 
Tablo 6. Araştırmaya Katılan Mezun Öğrencilerin Kariyer Kaynakları Bakımından

Dağılımları

\begin{tabular}{lrr}
\hline Arkadaş, tanıdık & 41 & $\% 22,7$ \\
\hline İş veren web sitesi & 43 & $\% 23,8$ \\
\hline Kariyer siteleri & $\mathbf{6 6}$ & $\mathbf{\% 3 6 , 5}$ \\
\hline İşverenle şahsen irtibat & 22 & $\% 12,2$ \\
\hline İşveren tanitım stnd & 4 & $\% 2,2$ \\
\hline Staj & 5 & $\% 2,8$ \\
\hline Toplam & $\mathbf{1 8 1}$ & $\mathbf{\% 1 0 0 , 0}$ \\
\hline
\end{tabular}

Kariyer Kaynağı Olarak, Kariyer Sitelerini Seçen Katılımcıların Seçtikleri Kariyer Siteleri Bakımindan Incelenmesi

Tablo 7'deki veriler incelendiğinde kariyer sitelerini seçen kişilerin büyük bir bölümünün (49kişi; \%74,2) kariyer.net internet sitesinden yararlandıkları görülmektedir. Bunu 12 kişi $(\% 18,2)$ ile memurlar.net, 3 kişi $(\% 4,5)$ yenibiriş.com ve 2 kişi $(\% 3,0)$ ile secretcv.com sitelerini bildirilmiştir.

Tablo 7. Araştırmaya Katılan Mezun Öğrencilerin Kariyer Kaynakları Bakımından Dağılımları

\begin{tabular}{lrr}
\hline kariyer.net & 49 & $\% 74,2$ \\
\hline yenibiriş.com & 3 & $\% 4,5$ \\
\hline memurlar.net & 12 & $\% 18,2$ \\
\hline secretcv.com & 2 & $\% 3,0$ \\
\hline Toplam & $\mathbf{6 6}$ & $\mathbf{\% 1 0 0 , 0}$ \\
\hline
\end{tabular}

Araştırmaya Katılan Kişilerin Meslek Fuarlarının Kariyerlerine Katkısı Bakımından Incelenmesi

Meslek fuarlarının kariyerlerine katkısı bakımından, araştırmaya katılan kişilerden 100'ü $(\% 46,3)$ MCBÜ Kariyer Günlerinden faydalandıklarını belirtmişlerdir. 100'ü $(\% 46,3)$ bu anlamda hiç bir kariyer fuarından yararlanmadıklarını belirtirken, 16 kişinin ise $(\% 7,4)$ Türkiye Bilimsel ve Teknolojik Araştırma Kurumu (TÜBİTAK), Tüm Yapım Fuarcılık Yapım A.Ş. (TÜYAP), AssociationInternationaledesÉtudiants en SciencesÉconomiques et Commerciales/Öğrenci Organizasyonu (AISEC) ve Center For Office and Information Technology (CEBIT) gibi meslek fuarlarından yararlandıkları kaydedilmiştir (Tablo 8). 
Tablo 8. Araştırmaya Katılan Mezun Öğrencilerin Meslek Fuarlarının Kariyerlerine Katkısı Bakımından Dağılımları

\begin{tabular}{lrr}
\hline MCBÜ Kariyer günleri & 100 & $\% 46,3$ \\
\hline TUBİTAK & 5 & $\% 2,3$ \\
\hline TUYAP & 7 & $\% 3,2$ \\
\hline AISEC & 2 & $\%, 9$ \\
\hline CEBİT & 2 & $\%, 9$ \\
\hline Hiç biri & 100 & $\% 46,3$ \\
\hline Toplam & $\mathbf{2 1 6}$ & $\mathbf{\% 1 0 0 , 0}$ \\
\hline
\end{tabular}

Bankacılık ve Finans Bölümünün Araştırmaya Katılan Öğrencilerin Kariyerlerine Katkı Düzeyi Bakımından Incelenmesi

Araştırmaya katılan ve çalışma hayatının içinde olan 181 kişinin, okudukları bölümün kariyerlerine katkısı bakımından dağılımları incelendiğinde; 91'inin (\%50,3) "hiç", 40'ının $(\% 22,1)$ "az" ve sadece 10'unun $(\% 5,5)$ "çok" cevabını verdikleri görülmüştür (Tablo 9).

Tablo 9. Bankacılık ve Finans Bölümünün Mezun Öğrencilerin Kariyerlerine Katkı Düzeyi Bakımından Dağılımı

\begin{tabular}{lcc}
\hline Çok & 10 & $\% 5,5$ \\
\hline $\mathrm{Az}$ & 40 & $\% 22,1$ \\
\hline Hiç & 91 & $\% 50,3$ \\
\hline Toplam & $\mathbf{1 8 1}$ & $\mathbf{0 1 0 0}$ \\
\hline
\end{tabular}

Araştırmaya Katılan Kişilerin Bankacılık ve Finans Bölümünden Mezun Olmaktan Duydukları Memnuniyet Düzeylerinin Incelenmesi

Araştırmaya katılan 216 kişiden 105'i $(\% 48,6)$ bankacılık ve finans bölümünden mezun olmaktan memnunken, 51'inin (\%23,6) memnun olmadıkları ve $80^{\prime}$ inin ise $(27,8)$ bu anlamda kararsız oldukları anlaşılmıştır (Tablo 10).

Tablo 10. Araştırmaya Katılan Mezun Öğrencilerin Bankacılık ve Finans Bölümünden Mezun Olmaktan Duydukları Memnuniyet Düzeylerinin Dağılımı

\begin{tabular}{lcc}
\hline Evet & 105 & $\% 48,6$ \\
\hline Hayır & 51 & $\% 23,6$ \\
\hline Kararsızım & 80 & $\% 27,8$ \\
\hline Toplam & $\mathbf{2 1 6}$ & $\mathbf{\% 1 0 0}$ \\
\hline
\end{tabular}

Bankacılık ve Finans Sektöründe Çalışan Kişilerin İşe Giriş ve Yükselmelerinde İstenen Belgeler Bakımından Incelenmesi

Araştırmada mevcut ve gelecekteki öğrencilerimize yol göstermesi bakımından bankacılık ve finansla ilgili sektörlerde çalışan 95 kişiden, işe giriş ve yükselmelerinde gerekli olan belgelerin neler olduğuna dair açık uçlu soru yöneltilerek, cevapları istenmiştir. 32'si bu anlamda 
SEGEM belgesinin, 27'si SPL/SPK belgelerinin, 10'u BES belgesinin istendiğini, 26'sı ise hiç bir belgenin istenmediğini belirtmiştir (Tablo 11).

Tablo 11. Bankacılık ve Finans Sektöründe Çalışan Mezun Öğrencilerden İşe Giriş ve Yükselmelerinde İstenen Belgeler Bakımından Dağılımları

\begin{tabular}{lc} 
Belgeler & Kişi Sayısı \\
\hline SEGEM & 32 \\
\hline SPL/SPK & 27 \\
\hline BES & 10 \\
\hline Hiç biri & 26 \\
\hline Toplam & $\mathbf{9 5}$ \\
\hline
\end{tabular}

Araştırmaya Katılanların Okulun/Bölümün Ĕ̆itim-Öğretim Kalitesinin Artırlmasına İlişkin Görüş ve Önerilerinin İncelenmesi

Araştırmaya katılanlara açık uçlu olarak sorular sorularak, okulun eğitim-öğretim kalitesinin artırılmasına ilişkin görüş ve önerileri alınmıştır. Bu soruya toplamda 66 kişi yanıt vermiştir (Tablo 12).

Tablo 12. Araştırmaya Katılanların Mezun Öğrencilerin Okulun/Bölümün Eğitim-Öğretim Kalitesinin Artırılmasına İlişkin Görüş ve Önerileri

\begin{tabular}{c|c}
\hline $\begin{array}{c}\text { Uygulama Derslerinin Artırılması } \\
(33) \% 50\end{array}$ & $\begin{array}{c}\text { Uygulamaya Yönelik Bilgisayar Programlarının } \\
\text { Öğretilmesi } \\
(2)(\% 3)\end{array}$ \\
\hline $\begin{array}{c}\text { Kariyer Yönlendirme ve Uygulamalı } \\
\text { Seminer/Eğitimler } \\
(13) \% 19\end{array}$ & $\begin{array}{c}\text { Ders saatlerinin kısaltılması/esneklik } \\
(2)(\% 3)\end{array}$ \\
\hline $\begin{array}{c}\text { Yabancı Dile Daha Fazla Ağırlık vermek/ } \\
\text { Ders Saatlerinin Artırlması } \\
(7)(\% 10)\end{array}$ & $\begin{array}{c}\text { Erasmus ve Avrupa Gönülllük Programlarında } \\
\text { İyileştirmeler } \\
(1)(\% 2)\end{array}$ \\
\hline $\begin{array}{c}\text { İntörn Eğitimin İyileştirilmesi/ Süresinin } \\
\text { uzatılması } \\
(4)(\% 6)\end{array}$ & $\begin{array}{c}\text { İkinci Öğretime Yönelik Etkinlikleri Yapılması } \\
(1)(\% 2)\end{array}$ \\
\hline Banka Simülasyonu/Finans Laboratuvarı & \\
(3) (\%5) & \\
\hline \hline
\end{tabular}

Uygulama derslerinin arttırılması 33 kişi tarafından önerilerek yüzde 50 oranıyla en yüksek dilimi kaplamaktadır. Kariyer Yönlendirme ve Uygulamalı Seminer/Eğitimler yüzde 19 oranında 13 kişi tarafından önerilmiştir. Yabancı Dile Daha Fazla Ağırlık Vermek/ Yabancı Dil Ders Saatlerinin Artırılması yüzde 10 düzeyinde 7 kişi tarafından, İntörn Eğitimin İyileştirilmesi/ Süresinin uzatılması yüzde 6'da yer alan 4 kişi tarafından, Banka Simülasyonu/Finans Laboratuvarı yüzde 5 oranında 3 kişi tarafından bildirilen önerilerdir. Uygulamaya Yönelik Bilgisayar Programlarının Öğretilmesi ve Ders saatlerinin kısaltılması/esneklik yüzde 3'de bulunan 2'şer kişi tarafından, Erasmus ve Avrupa Gönülllük 
Programlarında İyileştirmeler ve İkinci Öğretime Yönelik Etkinliklerin Yapılması yüzde 2’lik dilimde bulunan 1'er kişi tarafından sunulan diğer öneriler olarak kaydedilmiştir.

\section{Sonuç ve Öneriler}

Yapılan çalışma sonucunda 2006-2019 yılları arasında Bankacılık ve Finans Bölümünden mezun öğrencilerimizin e-mail ve telefonlarına gönderilen anket ile demografik özellikleri, eğitim-öğretim durumları, kariyer görünümleri, çalışma hayatının içinde olup olmadıkları, eğitim ve öğretimini aldıkları bankacılık ve finans alanında mı yoksa başkaca bir alanda mı işgücü piyasasında yer edindikleri, bölüm hakkında öneri ve görüşleri incelenmiştir. Bulgularının literatür kapsamında incelenen yazınlardaki sonuçlarla benzer doğrultuda olduğu görülen araştırmanın sonuçları maddeler halinde aşağıda sıralanmıştır.

Araştırmaya katılım gösteren mezun öğrencilerin;

a. 2012 yılı ve sonrasında yoğunlaşma gösterdikleri,

b. 2009-2011 yıllarından sadece 3'er kişinin katıldığ 1 dikkate alındığında; öğrencilerin zamanla iletişim adreslerini değiştirdikleri o nedenle iletişim kurulamadığı,

c. Örneklemi oluşturan mezun öğrencilerin 500 kadarının e-mail ve telefon numaralarının ulaşılabilir/güncel olduğu ve kendilerine anket sorularının internet üzerinden yönlendirildiği,

d. 216 mezun öğrencinin 181'inin çalışma hayatının içinde ekonomiye katkı sağladıkları sadece 35 öğrencimizin istihdam dışı kaldığı,

e. Çalışma hayatının içinde yer alanların yaklaşık yüzde 57'sinin (102 kişi) kadın bireylerden oluştuğu,

f. Çalışanların yüzde 53'ünü oluşturan 95 kişinin eğitim ve öğretimini aldıkları bankacılık ve finans alanında faaliyette bulunduğu, 86 kişiden oluşan yüzde 47,5' inin başkaca sektörlerde istihdam imkanı bulduğu,

g. Araştırmaya katılan kişilerin 88'inin erkek (\%40,7), 128'inin (\%59,3) kadın katılımcılardan oluştuğu,

h. Medeni durum açısından 140 kişi $(\% 64,8)$ bekarken, 76'sının $(\% 35,2)$ evli olduğu, * Katılımcıların yüzde 45.4'ünün (98 kişi) 27-30 yaş aralığında, yüzde 43.1'inin (93 kişi) 23-26 yaş aralığında, yüzde $8.8^{\prime}$ inin (19 kişi) 30 yaşından büyük ve yüzde 2.8'i oluşturan 6 kişinin 23 yaşından küçük olduğu,

i. Üniversitedeki başarı düzeyi bakımından 154 kişinin $(\% 7,3)$ kendini başarılı, 30 kişinin başarısız $(\% 13,9), 32$ kişinin ise $(\% 14,8)$ vasat buldukları,

j. Büyük bir bölümünün $(193 ; \% 89,4)$ lisans mezunu olduğu, 21 kişinin yüksek lisans $(\% 9,7), 2$ kişinin de $(\% 0,9)$ doktora yaptığ

k. Araştırmaya katılan 178 kişinin (\%82,4) en azından bir yabancı dil bildiği, 38 kişinin $(\% 17,6)$ yabancı dil bilmediği, yabancı dil bilen kişilerden sadece 7 'sinin $(\% 3,9)$ yabancı dil düzeyinin çok iyi olduğu, 59 kişinin $(\% 33,1)$ iyi ve 112 kişinin ise $(\% 62,9)$ orta düzeyde olduğu, 
1. Araştırmaya katılan mezun öğrencilerin 181 'inin $(\% 83,8)$ çalıştı̆̆ 1,35 kişinin $(\% 16,2)$ çalışmadığı, çalışan 181 kişinin çalıştığı sektörlere göre dağılımları incelendiğinde; 114 'ünün (\%63.0) özel sektör ve 59'unun $(\% 32,6)$ kamu sektöründe istihdam imkanı bulduğu, $8^{\prime}$ inin $(\% 4,4)$ ise kendi işlerini kurduğu,

m. İstihdam edildikleri iş yerlerindeki statüleri bakımından büyük bir bölümünün (91 kişi; \%50,3) memur olduğu, 40 kişinin $(\% 22,1)$ orta kademe yönetici, 38 kişinin $(\% 21,0)$ işçi ve 10 kişinin $(\% 5,5)$ üst kademe yönetici olduğu, 2 kişinin $(\% 1,1)$ akademik personel olarak görev yaptığ1,

n. Ortalama aylık gelir açısından araştırmaya katılan çalışan kişilerin büyük bir bölümünün (122 kişi; \%67,4), 4.000 TL'nin altında bir gelire sahip olduğu, 40 kişinin 4.000-5.500 TL (\%22,1), 13 kişinin 5.501- 7.000 TL $(\% 7,2)$ ve sadece 6'sının $(\% 3,3) 7.000$ TL'nin üstünde bir gelir elde ettiği,

o. 181 kişiden 79 'unun erkek, 102'sinin kadın bireylerden oluştuğu, erkeklerin yaklaşık yüzde 42'sini oluşturan 33 kişi tahsilini gördükleri bankacılık ve finans alanında çalışırken, bu oranın kadınlarda \%60'a çıktığı,

p. Çalışan katılımcılardan $98^{\prime}$ inin $(\% 45,4)$ çalışmaya başladıkları yıldan itibaren hiç iş değiştirmemiş kişilerden oluştuğu, 3 ve 3 'ten fazla iş değiştirenlerin sayısı 29 (\%13,4) iken, 34 kişinin $(\% 15,7)$ bir kere, 30 kişinin $(\% 13,9) 2$ kere iş değiştirdiği, araştırmaya katılan 35 kişinin ise mezun olduktan sonra hiç çalışmadığı,

q. Çalışan katılımcıların okudukları bölümün kariyerlerine katkısı bakımından dağılımlarına bakıldığında, 91'inin (\%50,3) "hiç", 40'ının (\%22,1) "az" ve sadece 10 'unun $(\% 5,5)$ "çok" cevabını verdikleri,

r. Kariyer kaynakları bakımından, araştırmaya katılan ve çalışan 181 kişiden 66'sının $(\% 36,5)$ kariyer sitelerinden, 41 kişinin $(\% 22,7)$ arkadaş ve/veya tanıdık, 43'ünün $(\% 23,8)$ işveren web sitesi, 22'sinin $(\% 12,2)$ işverenle şahsen irtibat kurarak, 4 'ünün $(\% 2,2)$ işveren tanıtım standları ve 5 'inin de $(\% 2,8)$ intörn staj programlarını kariyer kaynakları olarak belirttiği,

s. Kariyer kaynağı olarak kariyer sitelerini seçen kişilerin büyük bir bölümünün (49 kişi; $\% 74,2)$ kariyer.net internet sitesinden, 12 kişinin $(\% 18,2)$ memurlar.net, 3 kişinin $(\% 4,5)$ yenibiriş.com ve 2 kişinin $(\% 3,0)$ secretcv.com kariyer sitelerinden yararlandığ

t. Araştırmaya katılan kişilerden 100'ünün (yüzde 46,3) MCBÜ Kariyer Günlerinden faydalandığı, 100 kişinin (yüzde 46,3) bu anlamda hiç bir kariyer fuarından yararlanmadığını belirttiği, 16 kişinin (yüzde 7,4) TUBITTAK, TUYAP, AISEC ve CEBIT gibi meslek fuarlarından yararlandıkları,

u. Araştırmaya katılan 216 kişiden 105 ' i $(\% 48,6)$ Bankacılık ve Finans Bölümünden mezun olmaktan memnunken, 51'inin $(\% 23,6)$ memnun olmadı̆̆ 1,80 'inin ise $(27,8)$ bu anlamda kararsız olduğu,

v. 95 kişinin (\%44) iş alanı ile olan çalışmalardan, 70 kişinin $(\% 32,4)$ ise sosyal ve kültürel etkinliklere katılımdan faydalandıkları, 9 kişinin $(\% 4,2)$ alan dışı uygulamalara katılmaktan, 4 kişi $(\% 1,9)$ ise yabancı bir ülkede öğrenim ve çalışma bakımından deneyim elde ettiklerini, 38 kişinin $(\% 17,6)$ belirtilen değişkenlerden hiç birinden herhangi bir deneyim kazanmadığı, 
w. Araştırmaya katılan ve çalışma hayatında olan kişilerden 32'sinin Sigortacılık Eğitim Merkezi (SEGEM) belgesinin, 27'sinin SPL/SPK belgelerinin, 10'unun BES belgesinin istendiğini, 26'sının hiç bir belgenin istenmediğini bildirdiği tespit edilmiştir.

x. Araştırma kapsamındaki örnekleme yöneltilen açık uçlu sorularla bölümün eğitimöğretim kalitesinin arttırılması amaçlanmıştır. Verilen yanıtlar yoğunluk sırasına göre şöyle sıralanmaktadır;

i. Uygulama derslerinin arttırılması 33 kişi tarafından önerilerek yüzde 50 oranıyla en yüksek dilimi kapladı̆̆ı,

ii. Kariyer Yönlendirme ve Uygulamalı Seminer/Eğitimler yüzde 19 oranında 13 kişi tarafından önerildiği,

iii. Yabancı Dile Daha Fazla Ağırlık Vermek/ Yabancı Dil Ders Saatlerinin Artırılması yüzde 10 düzeyinde 7 kişi tarafından bildirildiği,

iv. İntörn Eğitimin İyileştirilmesi/ Süresinin uzatılması yüzde $6^{\prime}$ da yer alan 4 kişi tarafından,

v. Banka Simülasyonu/Finans Laboratuvarı yüzde 5 oranında 3 kişi tarafından bildirildiği,

vi. Uygulamaya Yönelik Bilgisayar Programlarının Öğretilmesi ve Ders saatlerinin kısaltılması/esneklik yüzde 3' de bulunan 2'şer kişi tarafından,

vii.Erasmus ve Avrupa Gönülllük Programlarında İyileştirmeler ve İkinci Öğretime Yönelik Etkinliklerin Yapılması yüzde 2'lik dilimde bulunan 1'er kişi tarafından sunulan diğer öneriler olarak kaydedilmiştir.

Araştırma sonuçlarına göre öncelikle öğrencilerin iletişim ve kariyerlerine ilişkin bilgilerin sinırlı olduğu açıktır. Bu anlamda okula kayıt edildikleri ilk aşamada @cbu.edu.tr e-mailleri ve ikametgah adresleri yanı sıra okuldan mezun olunduktan sonra da iletişimin sağlıklı bir şekilde sürdürülebilmesi adına e-mail adresleri, telefon numaraları şeklinde gerekli iletişim bilgilerinin alınarak değişiklik olduğunda güncellenebilmesinin sağlanması yönünde bir adım atılabilir. Bununla birlikte öğrencilerimizin mezun olup iş hayatına katıldıklarında kariyer yaşam çizgilerinin ne yönde ilerlediğinin daha yakınen izlenebilmesi için Mezun Takip Sistemi'nin okulumuz nezdinde kurulması önerilebilir. Ders programının incelenip, tekrar gözden geçirilerek uygulamalı derslerin artırılması, Banka Simülasyonu/Finans Laboratuvarı gibi ortamların oluşturulması öğrencilerimize bölümleriyle ilgili katkı seviyelerinin arttırılması adına önemli adımlar olabilir. Uluslararası ticaretin gelişmesi yanı sıra küreselleşmenin de katkısıyla banka ve finans kurumlarının şube, temsilcilik, muhabir banka $\mathrm{vb}$ şekilde bağlantılarla gerek yurt içi gerekse yurtdışı faaliyetlerde bulunabiliyor olmaları istihdam edecekleri personelin yabancı dil bilgisine sahip olmasını kaçınılmaz kılmaktadır. Bu bağlamda bir değil hatta ikinci yabancı dilin de verilmesi yönünde programın yeniden dizayn edilmesi uygun olacaktır. Öğrencilerin kariyer gelişimi bakımdan büyük önem arz eden intörn eğitiminin daha etkin ve kapsayıcı olabilmesi için banka ve finans kurumlarıyla birebir görüşmelerin gerçekleştirilerek kurumlar nezdinde protokol imzalanması ve bu anlamda uygulanmasına kurumsallık kazandırılmasının, öğrencilere iş yeri bulabilme ve kariyerlerini devam ettirme konusunda destek sağlayacağı söylenebilir. 
Sonuç olarak; mezun öğrencilerimizin istihdam edilebilmeleri ve hangi sektörlerde iş imkanı bulabildiklerini inceleyen çalışmamızda, örneklemi oluşturan 216 mezun öğrencinin 181'inin iş hayatı içinde olmaları ve bu kişilerden yüzde 52.5'ini oluşturan 95 kişinin üniversite hayatında okudukları bankacılık ve finans bölümleriyle alakalı sektörlerde çalışıyor olmaları, 15-24 yaş grubunu kapsayan genç nüfusta işsizlik oranının yüzde 24,7 olduğu (TÜİK, 2021) ülkemizde, okulumuz adına bir başarı olarak değerlendirilmiştir.

İlerleyen zamanlarda araştırma kapsamının genişletilerek, banka ve finans sektörünün personel istihdamında beklenti ve tercihleri yönünde saha araştırmalarının yapılmasıyla sektör beklentilerinin analiz edilmesi, böylece geleceğe dönük bankacılık ve finans sektörü çalışanlarının nitelik ve kalitelerinin arttırılmasına katkı sağlayacak çalışmaların yapılması önerilebilir.

\section{Teşekkür ve Bilgilendirme}

Bu yayın, Manisa Celal Bayar Üniversitesi Bilimsel Araştırma Projeleri Koordinasyon Birimi tarafından 2019/111 numarası ile desteklenen projeden türetilmiştir.

\section{Açıklamalar}

Çalışma proje kapsamında gerçekleştirilen bir araştırmanın ürünü olduğundan, proje sürecinde Etik Kurul Raporu alınmıştır. 


\section{Kaynakça}

Acaray, S., \& Pelenk, E. (2018). Örgüt İklimi ve Mesleki Bağhllık Arasındaki İlişki: Bankacılık ve Finans Sektöründe Staj Yapan Öğrenciler Üzerinde Bir Araştırma, 1. Uluslararası Bankacılık Kongresi Bildiriler Kitabı, 4-5 Mayıs, Ankara, s. 1-9.

Altunışık, R., Coşkun, R., Bayraktaroğlu, S., \& Yıldırım, E. (2010). Sosyal Bilimlerde Araştırma Yöntemleri SPSS Uygulamal, Sakarya Yayıncllık, Sakarya.

Baştürk, Ş. (2018). Türkiye'de Bankacılık Sektörü İstihdamının Özellikleri: Enformasyonalizm Bağlamında Bir Değerlendirme, 1. Uluslararası Bankacılık Kongresi, Ankara, s: 116-120.

Çakır, Ö., \& Kellevezir, I.(2020). Yükseköğretim Mezunlarında İssizlik ve Nitelik Uyumsuzluğu Olgusu: UNI-VERI Araştırma Sonuçları Işı̆̆ında Bir Değerlendirme, Çalışma İlişkileri Dergisi, 1(Özel Sayı), 1-17.

Delikanlı, İ.U. (2011). Banka Dışı Kuruluşlarda Günlük Finansal Raporlama Faaliyetlerinin Kapsamı, Organizasyönel Yapısı ve Muhasebe Eğitiminden Beklentiler, XXX. Türkiye Muhasebe Eğitimi Sempozyumu, Antalya, s. 29-50.

Doğan, Z., Yorgancılar, F.N., Berkman, A.N., \& Arslan, S. (2016). Üniversitelerde Bankactlik ve Finans Lisans Ĕ̆itimi'nin Mesleki Yeterlilik Düzeyine Katkısı ve Sektör Talep Analizi, Niğde Üniversitesi İktisadi ve İdari Bilimler Dergisi, 9(3), 32-58.

Duramaz, S. (2018). Ege Bölgesi'nde Yer Alan Yükseköğretim Kurumlarında Lisans Düzeyinde Ĕ̆itim Veren Bankacılık ve Finans Bölümlerinin Etkinliklerinin Veri Zarflama Analizi ile Ölçülmesi, 5. Uluslararası Politik, Ekonomik ve Sosyal Araştırmalar Kongresi (5 th International Congress on Political, Economic and Social Studies/ ICPESS), Niğde, Bildiriler Kitabı, Cilt 2: Ekonomik Araştırmalar, s: 403-412.

Durkaya, M., \& Hüsnüoğlu, N. (2018). İstihdamda Ĕ̆itimin Rolü, Sosyal ve Beşeri Bilimler Araştırmaları Dergisi, 19(41), 51-70.

Erdoğan, M., Ulusoy, T., Atay, H., \& Dengel, D. (2018). Bankacıllk ve Finans Bölümlerinin Bankacılık ve Finans Sektörünün Nitelikli İşgücü İhtiyacın Karşılamadaki Rolü: Kastamonu Üniversitesi Bankacılık ve Finans Bölümü Bütünleşik Müfredatı, 1. Uluslararası Bankacılık Kongresi Bildiriler Kitabı, Ankara, s: 890.

Ergincan, T. (2010). Yükseköğretim Mezunlarının Uzmanlık Alanında İstihdam Sorunu ve İş Doyumu, T.C. Dokuz Eylül Üniversitesi, Sosyal Bilimler Enstitüsü, Çalışma Ekonomisi ve Endüstri İlişkileri Ana Bilim Dalı, İnsan Kaynakları Programı, Yayımlanmamış Yüksek Lisans Tezi, İzmir.

İbiş, C., \& Çelikdemir, N.Ç. (2011). Bankacılık Sektörünün Muhasebe Ĕ̆itiminden Beklentileri. XXX. Türkiye Muhasebe Eğitimi Sempozyumu, Antalya, s. 1-27. 
Karadeniz, Y., \& Özkan, Ç. (2021). Üniversite Öğrencilerinin Mezuniyet Sonrası Kariyer Beklentileri: Ayvacık Meslek Yüksekokulu Örneği, Manisa Celal Bayar Üniversitesi Sosyal Bilimler Dergisi, 19(2), 113-136.

Kozak, M.A., \& Dalkıranoğlu, T. (2013). Mezun Öğrencilerin Kariyer Algılamaları: Anadolu

Üniversitesi Örneğgi, Anadolu Üniversitesi Sosyal Bilimler Dergisi, 13(1), 41-52.

Reed, K.K., Srinivasan, N., \& Doty, D.H. (2009). Adapting Human And Social Capital to Impact Performance: SomeEmpiricalFindingsfromthe U.S. PersonalBankingSector, Journal Of ManagerialIssues, Spring, 21(1), 36-57.

Sarıül, H. (2013). A Comparison of Curriculum in Bankingand Finance Departments of TheTurkishUniversities, International Journal on New Trends in EducationandTheirImplications, $4(2), 114-125$.

Sarkis, Z. (1999). General CostStructure Analysis: Theoryand Application totheBankingIndustry, KluwerAcademicPublishers, NewYork, U.S.A. , s.117.

Sofyalığlu, Ç., Kartal, B., \& İncekırık, A. (2019). Manisa Celal Bayar Üniversitesi Personel ve Öğrencilerinin Profil ve Beklentilerinin Analizi, Manisa Ekonomisi ve Vizyonu Kitabi İçinde (Editör: Mustafa Tepeci vd), sf: 303-321. Detay Yayıncılık: Ankara.

Selim, S., Biçer, A., \& Aybarç, S. (2020). Yükseköğretimde Etkinlik Analizi; Seçilmiş OECD Ülkeleri Örneği, Adnan Menderes Üniversitesi Sosyal Bilimler Enstitüsü Dergisi, 7(2), 33-58.

TÜİK (2019), Hanehalkı İşgücü İstatistik Bülteni,

Erişim adresi: http://www.tuik.gov.tr/PreHaberBultenleri.do?id=30687

TÜİK, (2021). İşgücü İstatistikleri, Ocak 2021, Erişim Adresi:

https://data.tuik.gov.tr/Bulten/Index?p=Isgucu-Istatistikleri-Ocak-2021-

37486\#: :text=15\%2D24\%20ya\%C5\%9F\%20grubunu\%20kapsayan, artarak $\% 20 \% 30 \%$ 2C1\%20oldu.

Ural, A., \& Kılıç., İ. (2006). Bilimsel Araştırma Süreci ve SPSS İle Veri Analizi, Detay Yayıncılık, Ankara.

Ümmühan, E. (2019). Türkiye'de Yükseköğretim Mezunu Gençlerde İşsizlik Sorunu ve İşsiz-İşveren Taraflarına Göre Nedenleri: Kastamonu İli Örneği, T.C. Kastamonu Üniversitesi, Sosyal Bilimler Enstitüsü, İktisat Ana Bilim Dalı, YayımlanmamışYüksek Lisans Tezi, Kastamonu. WEF (2019) Dünya Rekabet Endeksi,

Erişim adresi: https://www.weforum.org/reports/how-to-enda-decade-of-lost-productivitygrowth

Yeşil, Y., \& Topbaş, M. (2018). Mesleki Ĕ̆itimde Öğrencilerin Motivasyonlarının ve Beklentilerinin Incelenmesi: Honaz Meslek Yüksekokulu'nda Bir Araştırma, Elektronik Sosyal Bilimler Dergisi, 17(67), 938-948. 
Ekler

1. Makalede Kullanılan Anket Formu

\section{Manisa Celal Bayar Üniversitesi Uygulamalı Bilimler Yüksekokulu Bankacılık ve Finans Bölümü Mezunu Öğrencilerinin Ekonomiye Katkılarının Tespitine Yönelik Bir Araştırma}

Bu anket ile Manisa Celal Bayar Üniversitesi Uygulamalı Bilimler Yüksekokulu Bankacılık ve Finans Bölümü Mezunu Öğrencilerinin kariyer gelişimi ve ekonomiye katkılarının incelenmesi amaçlanmıştır. Çalışma, Dr.Öğr. Öyesi Hatice Nur GERMiR tarafından yürütülmekte ve sonuçları ile bildiri ve yayn olarak ortaya konulup; literatüre katkı sağlanmasına çalışılacaktır. Anketin doldurulması yaklașık 2-3 dakika sürmektedir. Lütfen tüm soruları eksiksiz olarak yanıtlaynız. Verdiğiniz destek için teşekkürler. Bu anketi yanıtlamak gönüllük esasına dayanmaktadır. Dr.Öğretim Oyesi Hatice Nur Germir

İs Tel : : 02362012972

Cep Tel : : 05323781390

1. Adnz Soyadinz

2. Cinsiyetiniz

Yainızca bir şıkkı işaretleyin.

Kadn

Erkek

3. YașınIz 
Manisa Celal Bayar Üniversitesi Uygulamalı Bilimler Yüksekokulu Bankacılık ve Finans Bölümü Mezunu Öğrencilerinin Ekonomiye Katkılarının Tespitine Yönelik Bir Araştırma

4. Medeni Durumunuz

Yainızca bir șikkı ișaretieyin.

$\longrightarrow$ Evi

Bekar

Diğer:

5. Hangi Şehirde İkamet Etmektesiniz

6. Eğitim Durumunuz

Yalnızca bir şıkk işaretieyin.

Lise

Oniversite

Yükseklisans

Doktora

7. UBYO'dan Hangi Yll Mezun Oldunuz?

8. Mevcut İș Durumunuz

Yalnızca bir şikkı işaretieyin.

Calıșyor

Çalışmryor 
9. Hangi Sektörde Çalıșyorsunuz

Yalnizca bir şıkk ișaretieyin.

$\bigcirc$ Kamu

$\bigcirc$ özel

$\bigcirc$ Kendi İ̧̨im

$\bigcirc$ Diger:

10. Hangi firma ve/veya devlet kurumunda çalıșıyorsunuz? (Adını yazınız)

11. Mesbğiniz ve Unvantrız Nedir?

12. işYerindeki Statünüz Nedir

Yainıza bir șikkı işaretieyin.

$\bigcirc$ Ost Kademe Yönetici

Orta Kademe Yōnetici

$\bigcirc$ Memur

$\bigcirc$ işci

$\bigcirc$ Diger:

13. Ortalama Aylık Geliriniz

Yainızca bir șikkı işaretleyin.

4000 TL'den az

$4000-5500 \mathrm{TL}$

$\square 5501-7000 \mathrm{TL}$

7000 TLden fazla 
14. Çalışmaya Başadıktan Sonra Kaç İ̧̧eri Değiştirdiniz?

Yainızca bir şıkkı işaretieyin.

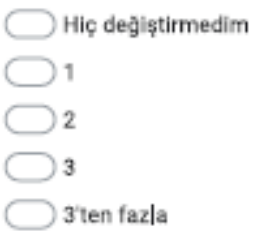

15. Akademik Başan Dũzeyinizi Nasıl Tarif Edersiniz

Yainızca bir şikkı işaretleyin.

Başarll.

Bą̧arısız

Vasat

16. Bankacilık ve Finans Bölūmũ Mezunu OImaktan Mưtu musunuz?

Yainızca bir şikkı işaretleyin.

$\bigcirc$ Evet

$\bigcirc$ Haylr

$\bigcirc$ Karars|zmm

17. Bankacilık ve Finans Bölūmũ Lisans Mezunu OImanızn Șu An Yaptı̉ını İ̧e Katkı Düzeyi Nedir?

Yainuzca bir șikkı ișaretleyin.

$\bigcirc_{\text {çok }}$
$\square_{\text {Hiç }}$ 
18. Hangi Yabanca Dilleri BIlyorsunuz

19. Yabana Di Seviyeniz

Yainızca bir şıkkı işaretleyin.

$\bigcirc$ çok iyi

$\bigcirc$ lyi

Orta

20. Kariyeriniz ile IIgli Hangi Kaynaklardan Bilgi Sağlacinız?

Yalnuzca bir şıkkı işaretieyin

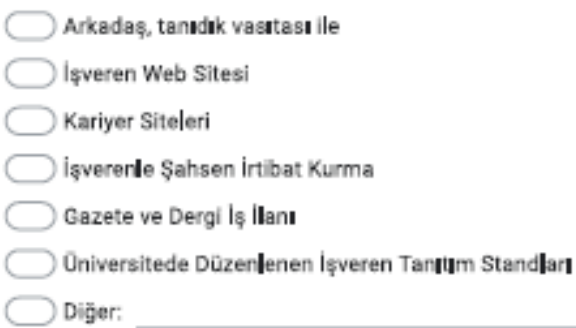

21. Hangi Internet Sitelerini Incelediniz ve Kariyeriniz ile Alakalı Sonuç Alabidiniz? Yalnızca bir șıkkı ișaretleyin.
Kariyer.net
Yenibiris.com
Memurlar.net
Secretcv.com
$\bigcirc$ Kariyergenc.com
$\bigcirc$ Diger: 
Manisa Celal Bayar Üniversitesi Uygulamalı Bilimler Yüksekokulu Bankacılık ve Finans Bölümü Mezunu Öğrencilerinin Ekonomiye Katkılarının Tespitine Yönelik Bir Araştırma

22. İ̧̧ Girişte ve Yükselmede Diploma Dłşında Başkaca Hangi Belgeler istend (SPLSPK vb.)

23. Universitede Ne Gibi Deneyimler Kazandınz?

Yainızca bir șıkkı işaretleyin.

Iร Alanı ile Olan Çalışmalar

Alan Dıșı Uygudamalara Katılim

Sosyal ve Kulturel etkirlikdere Katılim

Yabancı Bir Ôlkede Oğrenim ve Çalışma Imkanı

Diğer:

24. Hangi Meslek Fuarları Kariyerinize Daha Çok Katkı Sağladı?

Yainızca bir şıkkı işaretleyin

MCBÖ Kariyer Cünleri

TUBiTAK

TUYAP

AISEC

CEBI

Diger:

25. Okulumuzda eğitim ve öğretim kalitesinin artırlması adına öneri ve görüşleriniz varsa belirtiniz.

26. Illetişimimizi daha sürdürüleblir kılmak için mailnizi yaznız.

Deg̉erli katkıların|z için çok teşekkûr ederiz :))

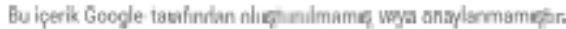

Google Formlar 